\title{
Eclogites of the North Atlantic Craton: Insights from the Chidliak eclogite xenoliths (S. Baffin Island, Canada)
}

\author{
V. Pobric ${ }^{1}$, N. KoroleV ${ }^{1,2, *}$ AND M. Kopylova ${ }^{1}$ \\ ${ }^{1}$ University of British Columbia, Dept. of Earth, Ocean and \\ Atmospheric Sciences, 2020 - 2207 Main Mall, \\ Vancouver V6T 1Z4, BC, Canada (* correspondence: \\ nkorolev@eoas.ubc.ca) \\ ${ }^{2}$ Saint-Petersburg State University, St. Petersburg, Russia, \\ Universitetskaya nab., 7-9, St. Petersburg 199034, Russia
}

The 156-138 Ma Chidliak kimberlites on the Eastern Hall Peninsula (EHP) of Baffin Island entrained mantle xenoliths interpreted to have been a part of the Archean North Atlantic Craton (NAC) mantle.

Eclogites account for $11 \%$ of all mantle xenoliths in Chidliack. We studied 19 Chidliak eclogite xenoliths that comprise 10 bimineralic, 5 rutile-bearing, 3 orthopyroxenebearing and one kyanite-bearing eclogites. The eclogites are classified into HREE-enriched, depleted and metasomatized based on their reconstructed whole rock REE patterns. All Chidliak eclogites are equilibrated in the diamond P-T field and cluster in two groups, low-temperature $\left(840-990{ }^{\circ} \mathrm{C}\right.$ at 4.1-5.0 GPa) and high-temperature $\left(\mathrm{T}>1320^{\circ} \mathrm{C}\right.$ at $\mathrm{P}>7.0$ $\mathrm{GPa})$. The eclogites resided in the peridotitic mantle affected by several metasomatic events, including an early pervasive silicate-carbonate metasomatism and a more recent $\mathrm{Ti}$ metasomatism at 180-215 km. The silicate-carbonate metasomatism is reflected in higher $\mathrm{Ce} / \mathrm{Yb}, \mathrm{Sr} / \mathrm{Y}, \mathrm{TiO} 2$ or $\mathrm{MgO}$ of the metasomatized group of eclogites. Only two samples may have formed after metamorphosed gabbro based on the presence of kyanite, high $\mathrm{Sr}$ content of garnet and positive Eu anomalies. Depleted Chidliak eclogites can be residues after $5-35 \%$ partial melting of Archean basalt after extraction of TTG from the EHP, as suggested by major and rare earth element modelling. The average contents of $\mathrm{MgO}$, $\mathrm{FeO}$ and $\mathrm{CaO}$ in NAC eclogites are statistically distinct from those in Slave craton eclogites with a probability of $>95 \%$. The former are more magnesian, less ferrous and calcic, contain more magnesian and less calcic garnets, and lower proportions of Group $\mathrm{C}$ eclogites partly because of more intense metasomatism. The $\mathrm{Mg}$ metasomatism is further evidenced by common development of secondary diopsiderich clinopyroxene and consistently more magnesian minerals in the eclogite xenoliths.compared to Chidliak eclogitic diamond inclusions. Beneath Chidliak, the deepest xenolith sampling in the very base of the thermal lithosphere (220 to $250 \mathrm{~km}$ ) is restricted only to eclogites. 